\title{
PENERAPAN MODEL PROBLEM BASED LEARNING (PBL) UNTUK MENINGKATKAN KEMAMPUAN BERPIKIR KRITIS SISWA BERBANTUAN APLIKASI MATH MOBILE LEARNING
}

\author{
Deni Yanti Nainggolan \\ Universitas Katolik Santo Thomas, Medan; \\ ndeniyanti@gmail.com
}

\begin{abstract}
Abstrak. Penelitian ini bertujuan untuk mengetahui apakah pembelajaran matematika dengan model Problem Based Learning (PBL) berbantuan aplikasi Math Mobile Learning dapat meningkatkan kemampuan berpikir kritis siswa pada pembelajaran matematika dengan materi segiempat dan segitiga kelas VII SMP Dharma Wanita Pertiwi Medan T.A 2018/2019. Jenis penelitian ini adalah penelitian tindakan kelas (PTK) yang dilakukan di kelas VII-1 SMP Dharma Wanita Pertiwi. Hasil temuan peneliti ini menunjukkan : (1) Siswa yang sudah mencapai Kriteria Ketuntasan Minimum (KKM) yaitu 75, diantaranya 17 orang (62,96\%) sedangkan yang belum mencapai KKM adalah 10 orang $(37,04 \%)$. Nilai rata-rata hasil tes kemampuan berpikir kritis matematis siswa pada siklus 1 mencapai 69,12. Jumlah siswa yang tuntas secara klasikal belum mencapai $75 \%$, maka dilanjutkan pada siklus II. Siswa yang sudah mencapai Kriteria Ketuntasan Minimum (KKM) adalah 21 orang $(77,78 \%)$ dan siswa yang belum mencapai KKM adalah 6 orang (22,22\%). Nilai rata-rata tes kemampuan berpikir kritis matematis siswa siklus II mencapai 77,33. (2) Pembelajaran model Problem Based Learning (PBL) berbantuan aplikasi Math Mobile Learning berlangsung dengan baik dan efektif untuk dilakukan terlihat dari lembar observasi aktivitas guru dan lembar observasi aktivitas siswa . Aktivitas guru pada siklus I, dengan rata-rata 60,90\% dan masih kriteria cukup baik, maka dilakukan tindakan selanjutnya untuk siklus II dan hasil lembar aktivitas guru meningkat pada siklus II dengan ratarata $80,90 \%$ dengan kriteria sangat baik. Hasil lembar observasi aktivitas siswa pada siklus I dengan rata-rata $58 \%$ dan masih kriteria cukup baik, sedangkan hasil observasi aktivitas guru meningkat pada siklus II dengan rata-rata $78 \%$ dengan kriteria baik. Hal ini menunjukkan bahwa penerapan model pembelajaran Problem Based Learning (PBL) berbantuan aplikasi Math Mobile Learning dapat digunakan untuk meningkatkan kemampuan berpikir kritis siswa kelas VII SMP pada materi segitiga dan segiempat.
\end{abstract}

Cartesius: Jurnal Pendidikan Matematika Vol. 3, No. 1

CProdi Pendidikan Matematika Universitas Katolik Santo Thomas 
Kata Kunci. PBL, berpikir kritis, math mobile learning.

\begin{abstract}
This study aims to determine whether mathematics learning with Problem Based Learning (PBL) models assisted by Math Mobile Learning applications can improve students' critical thinking skills in learning mathematics with quadrilateral and triangle material in class VII SMP Dharma Wanita Pertiwi Medan T.A 2018/2019. This type of research is a classroom action research (CAR) conducted in class VII-1 of the Dharma Wanita Pertiwi Middle School. The findings of this researcher show: (1) Students who have reached the Minimum Completion Criteria (KKM) are 75, including 17 people $(62.96 \%)$ while those who have not reached the KKM are 10 people (37.04\%). The average value of students' mathematical critical thinking ability test results in cycle 1 reached 69.12. The number of students who finished classically has not reached $75 \%$, then continued in cycle II. Students who have reached the Minimum Mastery Criteria (KKM) are 21 people (77.78\%) and students who have not reached the KKM are 6 people (22.22\%). The average value of the students' cycle II mathematical critical thinking skills reached 77.33. (2) The learning of Problem Based Learning (PBL) models assisted by the Math Mobile Learning application takes place properly and effectively to be seen from the teacher observation sheet and student activity observation sheet. Teacher activities in the first cycle, with an average of $60.90 \%$ and still quite good criteria, then the next action is taken for the second cycle and the results of the teacher activity sheet increase in the second cycle with an average of $80.90 \%$ with very good criteria. The results of observation of student activity sheets in the first cycle with an average of $58 \%$ and still quite good criteria, while the results of observations of teacher activity increased in the second cycle with an average of $78 \%$ with good criteria. This shows that the application of the Problem Based Learning (PBL) learning model assisted by the Math Mobile Learning application can be used to improve the critical thinking skills of Grade VII Middle School students on triangle and quadrilateral material.
\end{abstract}

Keywords. PBL, critical thinking, math mobile learning.

\title{
PENDAHULUAN
}

Pendidikan merupakan hal yang sangat penting dalam kehidupan manusia saat ini dalam pembentukan dan pengembangan kualitas sumber daya manusia dalam menghadapi kemajuan zaman. Hal ini sehubungan dengan yang dikemukakan oleh Suhartono (dalam Hidayati, 2015: 1) bahwa, Pendidikan adalah segala kegiatan pembelajaran yang berlangsung

Cartesius: Jurnal Pendidikan Matematika Vol. 3, No. 1

CProdi Pendidikan Matematika Universitas Katolik Santo Thomas 
sepanjang zaman dalam segala situasi kegiatan kehidupan. Selain itu mata pelajaran yang penting dalam pendidikan adalah matematika.

Matematika merupakan salah satu bidang studi yang menduduki peranan penting dalam pendidikan dan wajib dipelajari oleh semua siswa dari sejak Sekolah Dasar sampai Perguruan Tinggi.Mengingat pentingnya pendidikan matematika maka pembelajaran matematika merupakan hal yang penting untuk diperhatikan. Pada pembelajaran matematika diharapkan dapat membekali peserta didik dalam bernalar memecahkan masalah dan tidak hanya mengajarkan fakta dan konsep yang dialami dalam kehidupan seharihari. Hal tersebut sesuai dengan tujuan pembelajaran matematika di Indonesia yang ditermuat dalam Permendiknas Nomor 22 tahun 2006 (dalam Idris \& Kristina, 2016: 73) bertujuan agar peserta didik memiliki kemampuan yaitu:

1. Memahami konsep matematika dalam pemecahan masalah.

2. Menggunakan penalaran pada pola dan sifat.

3. Memecahkan masalah dari persoalan matematika.

4. Mengkomunikasikan gagasan dengan simbol untuk memperjelas masalah matematika.

5. Memiliki sikap menghargai mengenai kegunaan matematika dalam kehidupan sehari-hari.

Tetapi pada saat ini hasil dari pembelajaran matematika belum sesuai dengan tujuan pembelajaran matematika yang diharapkan.Hal ini juga terjadi pada siswa kelas VII SMP Dharma Wanita Pertiwi Medan. Berdasarkan hasil wawancara calon peneliti dengan guru matematika yaitu Bapak Bukhori beliau menyatakan bahwa proses pembelajaran yang berlangsung masih kurang baik. Hal ini disebabkan karena proses pembelajaran dikelas masih berpusat pada guru (teacher centered) dalam menyampaikan materi guru masih menggunakan metode ceramah, siswa kurang memperhatikan penjelasan guru, pertanyaan yang jarang muncul, kurangnya respon siswa dalam menjawab pertanyaan guru, hal ini menyebabkan proses pembelajaran menjadi pasif. Oleh karena itu, siswa belum terbiasa untuk merumuskan permasalahan ke dalam model matematika, siswa belum terbiasa memberikan langkah penyelesaian

Cartesius: Jurnal Pendidikan Matematika Vol. 3, No. 1

CProdi Pendidikan Matematika Universitas Katolik Santo Thomas 
masalah, dan siswa belum terbiasa untuk memilih strategi pemecahan masalah untuk menghasilkan kesimpulan yang benar dan tepat.

Berdasarkan data yang calon peneliti peroleh dari SMP Dharma Wanita Pertiwi Medan bahwa kemampuan matematika siswa masih rendah. Rendahnya kemampuan siswa dalam pembelajaran matematika dilihat dari hasil ujian bulanan dari beberapa kelas pada pembelajaran matematika Tahun Ajaran 2018/2019 ditunjukkan pada tabel dan gambar berikut:

Tabel 1. Nilai Formatif Siswa Kelas VII

\begin{tabular}{|c|c|c|c|c|c|}
\hline \multirow{2}{*}{ No. } & \multirow{2}{*}{ Kelas } & \multirow{2}{*}{$\begin{array}{c}\text { Jumlah } \\
\text { Siswa }\end{array}$} & \multicolumn{2}{|c|}{ Pencapaian KKM } & \multirow[t]{2}{*}{ KKM } \\
\hline & & & Tuntas & Tidak Tuntas & \\
\hline 1. & VII - 1 & 27 & 5 & 22 & \\
\hline 2. & $\mathrm{VII}-2$ & 25 & 4 & 21 & 75 \\
\hline & otal & 52 & $9(18 \%)$ & $43(82 \%)$ & \\
\hline
\end{tabular}

Sumber: SMP Dharma Wanita Pertiwi Medan Tahun Ajaran 2018/2019

Berdasarkan gambar di atas dapat disimpulkan bahwa hasil ujian bulanan matematika SMP Dharma Wanita Pertiwi Medan 82\% siswa tidak mecapai KKM yang telah di tetapkan yaitu 75. Oleh sebab itu diperlukan suatu usaha untuk memperbaiki kualitas pembelajaran matematika.Sehingga melalui perbaikan kualitas pembelajaran diharapkan tujuan pembelajaran matematika dapat tercapai secara optimal.

Pada proses pembelajaran matematika masih ditemukan masalah yang terkait dengan kemampuan berpikir. Oleh sebab itu kemampuan berpikir

Cartesius: Jurnal Pendidikan Matematika Vol. 3, No. 1

CProdi Pendidikan Matematika Universitas Katolik Santo Thomas 
pada siswa perlu dikembangkan dalam proses pembelajaran khususnya dalam pembelajaran matematika, dimana salah satunya adalah berpikir

\title{
Hasil Nilai Formatif
}

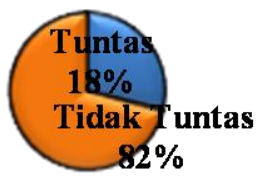

\author{
GTuntas \\ 口Tidak Tuntas
}

kritis dan sangat dibutuhkan siswa agar mampu bersikap rasional. Hal ini sebagaimana dikemukakan oleh Ennis (dalam Juhji, 2018: 21) menyatakan bahwa berpikir kritis adalah suatu proses berpikir yang bertujuan untuk membuat keputusan yang rasional dan diarahkan untuk mempertimbangkan serta mengevaluasi informasi yang pada akhirnya memungkinkan untuk melakukan sesuatu.

Berdasarkan minitest yang telah dilakukan di kelas VII-1 di Dharma Wanita Pertiwi Medan pada materi segiempat dan segitiga, banyak siswa masih kesulitan dalam menjawab soal yang diberikan. Adapun soal dan penyelesaian minites kemampuan berpikir kritis matematis siswa adalah sebagai berikut:

Soal 1: Tuliskan jenis-jenis segitiga berdasarkan panjang sisinya dan besar sudutnya? Beserta gambarnya!

Soal 2: Perhatikan gambar persegi PQRS di bawah ini!

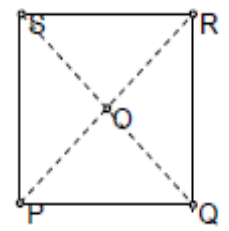

a. Bagaimanakan ukuran sudut QPR dan sudut QRP? Jelaskan jawabanmu!

b. Bagaimanakah ukuran sudut SQP dan sudut PSQ? Jelaskan jawabanmu!

Soal 3: ABCD merupakan sebuah persegi dengan panjang sisi $12 \mathrm{~cm}$. Jika EG

$=1 / 2 \mathrm{BC}$ dan $\mathrm{EF}=A D$. Hitunglah luas bangun yang diarsir pada gambar di samping ini! ABCD merupakan sebuah persegi dengan panjang sisi $12 \mathrm{~cm}$.

Cartesius: Jurnal Pendidikan Matematika Vol. 3, No. 1

CProdi Pendidikan Matematika Universitas Katolik Santo Thomas 


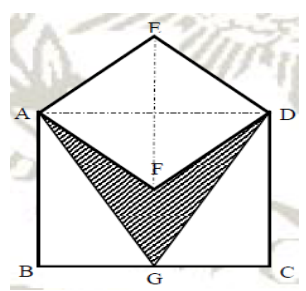

Berdasarkan hasil minites di atas dapat ditarik kesimpulan bahwa kemampuan berpikir kritis matematis siswa rendah. Sehubungan dengan hal tersebut, maka penting dilakukan perbaikan proses belajar mengajar dalam mendorong peningkatan kemampuan berpikir kritis matematis siswa. Salah satu upaya alternatif yang dilakukan adalah dengan menerapkan model pembelajaran yang dekat dengan kehidupan siswa sehari-hari salah satu model pembelajaran yang diharapkan dapat meningkatkan kemampuan berpikir kritis siswa adalah Problem based learning (PBL) karena melalui penerapan model tersebut siswa diberi kesempatan untuk menulis, berdiskusi, mendengar serta melakukan refleksi dan evaluasi dengan kelompok lain.

Problem based learning $(P B L)$ merupakan salah satu model pembelajaran inovatif yang memberi kondisi belajar aktif kepada siswa dalam kondisi dunia nyata. Hal ini sebagaimana dikemukakan oleh Moffit (dalam Rusman, 2016: 241) mengemukakan bahwa "Pembelajaran berbasis masalah merupakan suatu pendekatan pembelajaran yang menggunakan masalah dunia nyata sebagai suatu konteks bagi manusia untuk belajar tentang berpikir kritis dalam keterampilan pemecahan masalah serta untuk memperoleh pengetahuan dan konsep yang esensi dari materi pelajaran.

Model pembelajaran problem based learning (PBL) pada tahap orientasi terhadap masalah akan mengakibatkan proses pembelajaran berpusat pada siswa (Student Center) sehingga siswa dituntut aktif saat proses pembelajaran berlangsung karena guru menyajikan masalah nyata pada siswa. Pada tahap organisasi belajar siswa akan terbiasa mengidentifikasi masalah dan memberikan langkah-langkah penyelesaian masalah. Tahap penyelidikan individual maupun kelompok siswa akan terbiasa bertanya dan menjawab pertanyaan untuk menemukan penyelesaian masalah. Pada tahap pengembangan dan penyajian hasil penyelesaian masalah siswa terbiasa untuk Cartesius: Jurnal Pendidikan Matematika Vol. 3, No. 1

CProdi Pendidikan Matematika Universitas Katolik Santo Thomas 
mengidentifikasi atau menyelesaikan permasalahan ke dalam model matematika, tahap analisis dan evaluasi siswa terbiasa untuk melakukan refleksi atau evaluasi dan memilih strategi pemecahan masalah untuk menghasilkan kesimpulan yang tepat.

Mengingat perkembangan ICT yang semakin pesat di era informasional atau revolusi industri 4.0 maka sebaiknya dalam pembelajaran matematika menggunakan media berbasis android, salah satunya adalah Math Mobile Learning.Math Mobile Learning adalah aplikasi yang dibuat untuk melakukan perhitungan menjadi lebih cepat dan mudah memperoleh jawaban yang benar. Penggunaan media pembelajaran dengan menggunakan Math Mobile Learning diharapkan mendapat respon positif oleh siswa dan dijadikan sebagai sumber referensi siswa dalam membantu meningkatkan kemampuan berpikir kritis dengan menggunakan model Problem based learning (PBL).

Berdasarkan uraian di atas, maka model pembelajaran Problem Based Learning (PBL) berbantuan Math Mobile Learning merupakan salah satu solusi untuk meningkatkan kemampuan berpikir kritis matematis siswa. Oleh karena itu, perlu dilakukan penelitian terkait dengan Penerapan Model Problem Based Learning (PBL) Untuk Meningkatkan Kemampuan Berpikir Kritis Siswa Kelas VII SMP Dharma Wanita Pertiwi Medan Pada Materi Segitiga dan Segiempat Berbantuan Math Mobile Learning Tahun Ajaran 2018/2019.

\section{METODE}

Metode penelitian yang digunakan yaitu penelitian tindakan kelas.Pada penelitian tindakan kelas ini diharapkan dapat meningkatkan kualitas siswa baik dalam aspek pemahaman, maupun aspek-aspek lain yang bermanfaat bagi siswa untuk menjadi dewasa seutuhnya. Adapun prosedur penelitian tindakan kelas dengan model Kemmis dan McTaggart yang terdiri dari perencanaan tindakan (planning), pelaksanaan tindakan (acting), observasi (observing), dan refleksi (reflecting) Saur (2013 : 27). Dalam penelitian ini menggunakan penelitian kolaboratif yaitu guru bersama peneliti berkolaborasi dalam melakukan penelitian tindakan kelas ini.

Cartesius: Jurnal Pendidikan Matematika Vol. 3, No. 1

CProdi Pendidikan Matematika Universitas Katolik Santo Thomas 
Subjek penelitian ini adalah siswa kelas VII-1 SMP Dharma Wanita Pertiwi Medan Tahun Ajaran 2018/2019 dengan model pembelajaran Problem Based Learning (PBL).

Teknik pengumpulan data yang digunakan peneliti pada penelitian ini adalah tes dan non-tes.Teknik tes dalam penelitian ini menggunakan tes awal dan tes kemampuan berpikir kritis matematis pada setiap siklus.Soal tes berbentuk uraian sebanyak 4 soal disusun sesuai indikator kemampuan berpikir kritis matematis.Selanjutnya, teknik non-tes yang dimaksud pada penelitian ini menggunakan lembar observasi aktivitas guru dan dan lembar observasi aktivitas siswa.

\section{HASIL DAN PEMBAHASAN}

Hasil tes siswa pada tes awal, siklus I dan tes siklus II setiap tes diberikan 4 soal uraian, pada setiap soal terdapat indikator kemampuan berpikir kritisw matematis siswa. Secara keseluruhan hasil perolehan nilai rata - rata siswa pada tes awal, siklus I, tes siklus II dapat pada tabel berikut:

Tabel 2. Tingkat Kemampuan Berpikir Kritis Matematis

\begin{tabular}{lccc}
\hline \multicolumn{1}{c}{ Kategori } & Tes Awal & Tes Siklus I & $\begin{array}{c}\text { Tes Siklus } \\
\text { II }\end{array}$ \\
\hline Nilai Terendah & 0 & 25 & 50 \\
\hline Nilai Tertinggi & 100 & 100 & 100 \\
\hline Jumlah Siswa yang Tuntas & 11 Siswa & 17 Siswa & 21 Siswa \\
\hline $\begin{array}{l}\text { Jumlah Siswa yang Tidak } \\
\text { Tuntas }\end{array}$ & 16 Siswa & 10 Siswa & 6 Siswa \\
\hline Rata-rata & 66,83 & 69,12 & 77,33 \\
\hline Ketuntasan Klasikal & $40,74 \%$ & $62,96 \%$ & $77,78 \%$ \\
\hline
\end{tabular}

Dari tabel 2 dapat dilihat bahwa terjadi peningkatan yang diperoleh siswa dari tes awal, tes siklus I sampai tes siklus II. Pada nilai terendah siswa dan nilai tertinggi siswa adanya peningkatan dimana nilai terendah siswa juga terjadi peningkatan pada tes awal 0, siklus I bernilai 25 dan siklus II menjadi 50. Jumlah siswa yang tuntas juga adanya peningkatan pada tes awal, siklus I dan siklus II yaitu mulai dari 11 orang siswa menjadi 17 orang siswa dari 17 orang menjadi 21 orang siswa. Ketuntasan klasikal juga adanya peningkatan tes awal $40,74 \%$, disiklus I $62,96 \%$ menjadi $77,78 \%$.

Cartesius: Jurnal Pendidikan Matematika Vol. 3, No. 1

CProdi Pendidikan Matematika Universitas Katolik Santo Thomas 
Dalam setiap siklus dilakukan observasi atau pengamatan kepada guru selama proses pembelajaran berlangsung. Pengamatan dilakukan oleh guru bidang studi matematika juga disebut sebagai pengamat atau observer pada penelitian.Observer memberikan penilaian kepada peneliti yang bertindak sebagai guru dengan mengisi lembar observasi aktivitas guru. Pada setiap siklus dilakukan observasi aktivitas guru sebanyak dua kali sesuai dengan pertemuan pada masing-masing siklus. Berikut tabel perbandingan hasil persentase observasi aktivitas guru pada siklus I dan siklus II:

Tabel 3. Observasi Aktivitas Guru Pada Siklus I dan Siklus II

\begin{tabular}{lcccc}
\hline \multirow{2}{*}{ Pertemuan } & \multicolumn{2}{c}{ Siklus I } & \multicolumn{2}{c}{ Siklus II } \\
\cline { 2 - 5 } & Presentase & Kriteria & Presentase & Kriteria \\
\hline Pertama & $58,18 \%$ & Cukup & $70,90 \%$ & Baik \\
\hline Kedua & $63,63 \%$ & Baik & $90,90 \%$ & Sangat Baik \\
\hline $\begin{array}{l}\text { Rata-rata } \\
\text { Nilai }\end{array}$ & $\mathbf{6 0 , 9 0 \%}$ & Baik & $\mathbf{8 0 , 9 0 \%}$ & Sangat Baik \\
\hline
\end{tabular}

Dari tabel 3 dapat dilihat bahwa adanya peningkatan pada observasi aktivitas guru dalam siklus I dan siklus II. Pada siklus I rata-rata nilai observasi aktivitas guru yaitu 60,90\% dengan kriteria baik selanjutnya pada siklus II terjadi peningkatan menjadi $80,90 \%$ dengan kriteria sangat baik.

Setiap dilakukan pengamatan terhadap siswa selama proses pembelajaran berlangsung. Pengamatan dilakukan oleh guru bidang studi matematika sebagai observer pada penelitian.Observer memberikan penilaian terhadap siswa dengan mengisi lembar observasi aktivitas siswa.Pada tiap siklus dilakukan observasi aktivitas siswa sebanyak dua kali sesuai dengan pertemuan pada tiap siklus. Perbandingan hasil persentase observasi aktivitas siswa pada siklus I dan siklus II sebagai berikut:

Tabel 4. Hasil Observasi Aktivitas Siswa Pada Siklus I dan Siklus II

\begin{tabular}{lcccc}
\hline \multirow{2}{*}{ Pertemuan } & \multicolumn{2}{c}{ Siklus I } & \multicolumn{2}{c}{ Siklus II } \\
& Presentase & Kriteria & Presentase & Kriteria \\
\hline Pertama & $52 \%$ & Cukup Baik & $72 \%$ & Baik \\
\hline Kedua & $64 \%$ & Baik & $84 \%$ & Sangat Baik \\
\hline Rata-rata Nilai & $\mathbf{5 8 \%}$ & Cukup Baik & $\mathbf{7 8 \%}$ & Baik \\
\hline
\end{tabular}

Cartesius: Jurnal Pendidikan Matematika Vol. 3, No. 1

CProdi Pendidikan Matematika Universitas Katolik Santo Thomas 
Dari tabel 4 dapat dilihat bahwa adanya peningkatan hasil observasi aktivitas siswa pada siklus I dan Siklus II. Pada siklus I rata-rata nilai observasi aktivitas siswa yaitu 58\% dengan kriteria cukup baik kemudian pada siklus II terjadi peningkatan menjadi 78\% dengan kriteria baik.

\section{KESIMPULAN}

Berdasarkan hasil penelitian yang sudah dilaksanakan dengan menerapkan model pembelajaran Problem Based Learning (PBL) berbantuan Math Mobile Learning pada pembelajaran matematika pada materi segiempat dan segitiga dapat disimpulkan bahwa penerapan model Problem Based Learning (PBL) berbantuan Math Mobile Learning dapat meningkatkan kemampuan berpikir kritis matematis siswa di kelas VII-1 SMP Dharma Wanita Pertiwi Medan.

Hal tersebut dapat dibuktikan dari hasil tes kemampuan berpikir kritis matematis siswa yang diberikan, baik tes kemampuan awal, tes kemampuan berpikir kritis matematis siklus I, dan tes kemampuan berpikir kritis matematis siklus II. Pada tes kemampuan awal masih tergolong rendah yaitu diperoleh rata-rata sebesar 66,83. Siswa yang tuntas dalam belajar sebanyak 11 orang siswa dengan persentase klasikal sebanyak 40,74\%, sedangkan siswa yang tidak tuntas dalam belajar sebanyak 16 orang siswa dengan persentase sebesar $43,17 \%$. Hasil tes siklus I setelah menggunakan model prmbelajaran Problem Based Learning (PBL) berbantuan Math Mobile Learning diperoleh 69,12. Siswa yang tuntas dalam belajar sebanyak 17 orang siswa dengan persentase ketuntasan klasikal 62,96\%, sedangkan siswa yang tidak tuntas dalam belajar sebanyak 10 orang siswa dengan persentase 37,04\%. Pada siklus II setelah melakukan perbaikan pembelajaran Problem Based Learning (PBL) berbantuan Math Mobile Learning diperoleh rata-rata 69,12\%. Siswa yang tuntas dalam belajar sebanyak 21 orang siswa dengan persentase $77,78 \%$ sedangkan siswa yang tidak tuntas dalam belajar sebanyak 6 orang siswa dengan persentase $22,22 \%$.

Berdasarkan peningkatan yang terjadi pada hasil tes siklus II yang telah memenuhi indikator keberhasilan yaitu $\geq 75 \%$ maka dapat disimpulkan bahwa dengan menggunakan model pembelajaran Problem Based Learning (PBL) berbantuan Math Mobile Learning Dari hasil data yang diperoleh, dapat

Cartesius: Jurnal Pendidikan Matematika Vol. 3, No. 1

CProdi Pendidikan Matematika Universitas Katolik Santo Thomas 
disimpulkan bahwa dengan menggunakan model pembelajaran Problem Based Learning (PBL) berbantuan aplikasi math mobile learning dapat meningkatkan kemampuan berpikir kritis matematis siswa pada materi segiempat dan segitiga di kelas VII SMP Dharma Wanita Pertiwi Medan dapat diterapkan dan dilaksanakan dengan baik. Aktivitas pembelajaran guru dan siswa pada siklus II juga dikategorikan baik.

Adapun yang menjadi saran dalam pelaksanaan penelitan tindakan kelas (PTK) dan hasil penelitian yang telah diperoleh oleh peneliti, dapat ditemukan saran sebagai berikut:

1. Bagi siswa

Disarankan lebih berani dalam memberikan ide-ide matematik dan aktif dalam kegiatan belajar mengajar sehingga menemukan solusi permasalahan selama proses pembelajaran berlangsung serta lebih mengembangkan kemampuan berpikir kritis matematis siswa dan kemampuan-kemampuan matematika lainnya.

\section{Bagi Guru}

a. Hendaknya dapat menguasai penggunaan aplikasi android yang berhubungan dengan pembelajaran matematika sehingga pembelajaran menjadi bervariasi, khususnya guru dapat menguasai penggunaan aplikasi math mobile learning.

b. Penggunaan software matematika harus semakin ditingkatkan agar dapat menciptakan suasana yang baru dalam pembelajaran sehingga siswa dapat termotivasi dengan baik dan proses belajar mengajar yang menyenangkan

\section{Bagi Sekolah}

Memberikan dukungan baik sarana dan prasarana yang dapat meningkatkan kemampuan berpikir kritis matematis siswa dengan menerapkan model Problem Based Learning (PBL) berbantuan aplikasi Math Mobile Learning yang berdampak positif pada pembelajaran di dalam kelas.

4. Bagi Peneliti

Hendaknya melakukan penelitian tentang implementasi pembelajaran matematika berbantuan aplikasi Math Mobile Learning pada pokok bahasan yang berbeda.Selain itu, diharapkan kepada peneliti lebih lanjut

Cartesius: Jurnal Pendidikan Matematika Vol. 3, No. 1

CProdi Pendidikan Matematika Universitas Katolik Santo Thomas 
dapat meningkatkan kemampuan berpikir kritis siswa disemua indikator secara merata.

\section{UCAPAN TERIMAKASIH}

Penulis menyampaikan terimakasih kepada Bapak Arisan Candra Nainggolan, M.Pd. sebagai Dosen Pembimbing 1 dan Ibu Ribka Kariani Br. Sembiring, S.Si., M.Pd. sebagai Dosen Pembimbing 2 yang telah mengarahkan dan membimbing penulis mulai dari awal penelitian hingga berakhirnya penelitian sehingga penulis dapat menuliskan artikel ini yang merupakan bagian dari hasil penelitian penulis. Penulis juga menyampaikan terimakasih kepada Kepala Program Studi Pendidikan Matematika, Dekan, dan Rektor Universitas Katolik Santo Thomas atas dukungan yang diberikan kepada penulis.

\section{DAFTAR PUSTAKA}

[1] Arikunto, Suharsimin. 2010. Prosedur Penelitian Suatu Pendekatan Praktik. Jakarta: PT. Rineka Cipta.

[2] Arikunto, Suharsimin. 2010. Manajemen Penelitian. Jakarta: PT. Rineka Cipta.

[3] As'ari, Abdur Rahman, dkk. 2016. Matematika Semester 2 Kementerian Pendidikan dan Kebudayaan-Edisi Revisi.Jakarta: Kementerian Pendidikan dan Kebudayaan.

[4] Dasa Ismaimuza. 2010. Pengaruh Pembelajaran Berbasis Masalah dengan Strategi Konflik Kognitif Terhadap Kemampuan Berpikir Kritis Matematis dan Sikap Siswa SMP. Jurnal Pendidikan Matematika. 4(1).

[5] Fivi Nuraini. 2017. Penggunaan Model Problem Based Learning Untuk Meningkatkan Hasil Belajar IPA Siswa Kelas 5 SD. Jurnal Mitra Pendidikan. $1(4)$.

[6] Hasna Dewi Ritonga. 2017. Kemampuan Koneksi Matematika antara Penguasaan Pecahan dengan Hasil Belajar Matematika Materi SPLDV.Seminar Nasional Matematika.

Cartesius: Jurnal Pendidikan Matematika Vol. 3, No. 1

CProdi Pendidikan Matematika Universitas Katolik Santo Thomas 
[7] Husnidar, Ikhsan, dan Samsyul Rizal. 2014. Penerapan Model Pembelajaran Berbasis Masalah untuk Meningkatkan Kemampuan Berpikir Kritis dan Disposisi Matematis Siswa. Jurnal Didaktik Matematika. 1(1).

[8] Invany Idris. 2016. Penerapan Pendidikan Matematika Realistik Indonesia untuk Meningkatkan Kemampuan Penyelesaian Soal Cerita Pada Sekolah Menengah Pertama. Jurnal EduMat Sains. 1(1).

[9] Juhji. 2018. Profesi Guru dalam Mengembangkan Kemampuan Berpikir Kritis Peserta Didik di Era Globalisasi. Jurnal Genealogi PAI. 5(1).

[10] Jumaisyaroh, Napitupulu, dan Hasratuddin. 2014. Peningkatan Kemampuan Berpikir Kritis Matematis dan Kemandirian Belajar Siswa SMP Melalui Pembelajaran Berbasis Masalah. Jurnal Kreano. 5(2).

[11] Miftahul Husnah. 2017. Hubungan Tingkat Berpikir Kritis Terhadap Hasil Belajar Fisika Siswa Dengan Menerapkan Model Pembelajaran Problem Based Learning. Jurnal PASCAL. 1(2).

[12] Nur Hayadi. 2015. Hubungan Antara Efikasi Diri Akedemik Dengan Minat Melanjutkan Studi di Perguruan Tinggi Pada Siswa. Jurnal Bimbingan dan Konseling Edisi 11.

[13] Pradimas Sigit Permadi. 2016. Kolaborasi Model Pembelajaran Kooperatif Jigsaw dan Kancing Gemerincing untuk Meningkatkan Hasil Belajar Siswa. Jurnal Informasi dan Komunikasi Administrasi Perkantoran. 1(1).

[14] Putri Lestari, Adeng Hudayana. 2018. Penerapan Model Quantum Teaching Sebagai Upaya Meningkatkan Hasil Belajar Siswa.Research and Development Journal Of Education. 5(1).

[15] Rifaatul Mahmuzah. 2015. Peningkatan Kemampuan Berpikir Kritis Matematis Siswa SMP Melalui pendekatan Problem Posing. Jurnal Peluang. $4(1)$.

[16] Rochmad. 2016. Analisis Timeline dan Berpikir Kritis dalam Pemecahan Masalah Matematika pada Pembelajaran Kooperatif Resiprokal. Jurnal Kreano. Vol. 2.

Cartesius: Jurnal Pendidikan Matematika Vol. 3, No. 1

CProdi Pendidikan Matematika Universitas Katolik Santo Thomas 
[17] Rusman. 2015. Belajar dan Pembelajaran. Bandung: PT Kharisma Putra Utama.

[18] Slameto. 2017. Belajar dan Faktor - Faktor yang Mempengaruhinya. Jakarta : PT Rineka.

[19] Syuhada Sitompul, Laila Fitri. 2017. Upaya Meningkatkan Kemampuan Belajar Matematika Menggunakan Model Team Assisted Individualization Siswa MTS Tembung .Seminar Nasional Matematika.

[20] Tampubolon, Saur. 2014. Penelitian Tindakan Kelas Sebagai Pengembangan Profesi Pendidik dan Keilmuan. Jakarta: Erlangga.

[21] Trianto. 2011. Mendesain Model Pembelajaran Inovatif - Progresif. Jakarta: Kencana Prenada Media Group.

[22] Wahyudin Wisudawan. 2017. Pengembangan Aplikasi Math Mobile Learning Bangun Datar Berbasis Android Pada Materi Segitiga dan Segiempat Pelajaran Matematika di Tingkat SMP. Seminar Nasional Teknoka. Vol. 2. 